\title{
PELATIHAN SADARI DI SMA MUHAMMADIYAH 1 PEKANBARU
}

\author{
Eka Maya Saputri ${ }^{1)}$ Juli Selvi Yanti' ${ }^{2)}$ \\ ${ }^{1,2)}$ STIKes Hang Tuah Pekanbaru \\ Email :maya.eka72@yahoo.com
}

\begin{abstract}
ABSTRAK
Kanker payudara adalah suatu kondisi di mana sel telah kehilangan pengendalian dan mekanisme normalnya, sehingga mengalami pertumbuhan yang tidak normal, cepat dan tidak terkendali. SADARI merupakan kegiatan yang sangat penting untuk diketahui oleh remaja putri saat ini, karena $75-85 \%$ keganasan kanker payudara ditemukan pada saat pemeriksaan payudara sendiri. Berdasarkan data Sistem Infomasi Rumah Sakit (SIRS) bahwa kejadian Kanker payudara meningkat. Tujuan utama dari Pemeriksaan Payudara Sendiri (SADARI) adalah untuk menemukan kanker payudara dalam stadium dini sehingga pengobatannya menjadi lebih baik dan efektif. Metode yang digunakan dalam pengabdian masyarakat ini ada dua tahap yang pertama ceramah tanya jawab menggunakan infokus dan leaflet. Tahap kedua mendemonstrasikan menggunakan phantom payudara. Hasil dari kegiatan pengabdian masyarakat ini dapat bahwa meningkatnya pengetahuan siswi SMA Muhammadiyag 1 akan pentingnya SADARI dan siswi mau melaksanakan SADARI di rumah yang dilaksanakan setiap bulannya. Disarankan agar pihak sekolah dapat melaksanakan kegiatan serupa dan dapat mensosialisasikan kepada siswi- siswi selanjutnya.
\end{abstract}

Kata Kunci: SADARI, Remaja Putri, SMA Muhammadiyah 1

\begin{abstract}
Breast cancer is a condition in which the cell has lost its normal control and mechanism, so it experiences abnormal, fast and uncontrolled growth. BSE is a very important activity for young women to know at this time, because 75-85\% of breast cancer malignancies are found at the time of breast self-examination. Based on Hospital Information System (SIRS) data that the incidence of breast cancer is increasing. The main purpose of BSE is to find breast cancer in the early stages so that the treatment becomes better and more effective. The method used in community service is the first two stages of the question and answer lecture using infocus and leaflets. The second stage demonstrates using phantom breast. The results of this community service activity can be that increased student knowledge of the importance of BSE examination and female students willing to carry out BSE at home are held every month. it is recommended that the school can carry out similar activities and can socialize to the next students.
\end{abstract}

Key words: BSE, Young Women, Muhammadiyah High School 1 


\section{PENDAHULUAN}

Pemeriksaan payudara sendiri (SADARI) yaitu belajar melihat dan memeriksa payudara sendiri setiap bulan (Rasjidi, 2009). Tujuan utama dari SADARI adalah untuk menemukan kanker payudara dalam stadium dini sehingga pengobatannya menjadi lebih baik (Purwoastuti, 2008). Kanker payudara adalah suatu kondisi di mana sel telah kehilangan pengendalian dan mekanisme normalnya, sehingga mengalami pertumbuhan yang tidak normal, cepat dan tidak terkendali (Astana, 2009).

Kanker payudara merupakan penyebab kematian kedua akibat kanker pada wanita, setelah kanker leher rahim dan merupakan kanker yang paling banyak ditemui di antara wanita. Berdasarkan data dari American Cancer Society, sekitar 1,3 juta wanita terdiagnosis menderita kanker payudara, dan tiap tahunnya di seluruh dunia kurang lebih 465.000 wanita meninggal oleh karena penyakit ini. Probabilitas bagi seorang wanita di negara yang sudah maju untuk menderita kanker payudara adalah sebesar $4,8 \%$, sedangkan untuk negara yang sedang berkembang adalah 1,8\% (Rasjidi, 2009).

Berdasarkan data yang diperoleh dari RSUD Arifin Achmad Pekanbaru, prevalensi kanker payudara pada tahun 2010 sebanyak 200 kasus. Pada tahun 2011 sebanyak 172 kasus dan pada tahun 2012 terjadi peningkatan sebanyak 207 kasus. Sebagian besar kasus kejadian kanker payudara banyak terjadi pada usia 15-24 tahun sebanyak 50 orang, pada usia 25-44 tahun sebanyak 37 orang dan pada usia lebih dari 44 tahun sebanyak 29 orang

Kanker payudara masih mempunyai kemungkinan besar untuk disembuhkan jika ditemukan pada tahap awal atau dini. 75-85\% keganasan kanker payudara ditemukan pada saat dilakukan pemeriksaan payudara sendiri (Purwoastuti, 2008). Meskipun angka kejadian kanker payudara rendah pada wanita usia muda, namun sangat penting untuk diajarkan SADARI semasa muda agar terbiasa melakukannya di kala tua (Nugroho, 2011).

Adapun salah satu penyebab remaja tidak melaksanakan SADARI disebabkan karena remaja tersebut belum pernah mendapatkan informasi tenttang kesehatan reproduksi tentang SADARI baik dari guru maupun dari petugas kesehatan sehingga siswanya belum tahu apa itu SADARI dan bagaimana cara melakukan SADARI. Oleh karena itu penulis ingin melaksanakan penyuluhan dan pelatihan pelaksanaan SADARI di SMA Muhammadiyah Pekanbaru.

\section{METODE PELAKSANAAN}

Metode pengabdian masyarakat ini dilaksanakan dalam bentuk penyuluhan dan metode demonstrasi dengan menggunkan phanthom dimana model tersebut memberikan contoh langsung pelaksanaan SADARI kepada remaja putri, setelah didemontrasikan maka remaja putri dievaluasi untuk mempraktikkan langsung kepada panthom.

\section{HASIL DAN PEMBAHASAN}

\section{A. Hasil Pelaksanaan}

Kegiatan penyuluhan dan pelatihan pemeriksaan payudara sendiri (SADARI) telah dilaksanakan pada tanggal 20 Juli 2018 sebanyak 20 orang di Sekolah Menengah Atas Muhammadiyah 1 Pekanbaru. Berdasarkan wawancara, tanya jawab dan pengamatan langsung selama kegiatan pengabdian kepada masyarakat ini memberikan hasil sebagai berikur : 
1. Meningkatnya pengetahuan siswa SMA Muhammadiyah 1 tentang pelaksananan SADARI hal ini dapat nilai dari kemampuan siswa dalam menjawab pertanyaan yang diajukan oleh pemateri sebanyak 4 pertanyaan.

2. Seluruh siswi (100\%) mampu melakukkan praktik SADARI sesuai dengan yang telah diajarkan oleh pemateri dengan menggunakan phantom payudara.

3. Pada pelaksanaan evaluasi tahap II dari hasil kegiatan SADARI didapatkan bahwa siswa yang diberikan pelatihan sebanyak 20 orang

4. Pada tanggal 20 Juli 2018 dapat melakukan kegiatan SADARI dirumahnya dan 20 orang siswa tersebut dapat mengajarkan teman sekolah masing-masing 2-3 orang teman sekolahnya untuk dapat melakukan SADARI

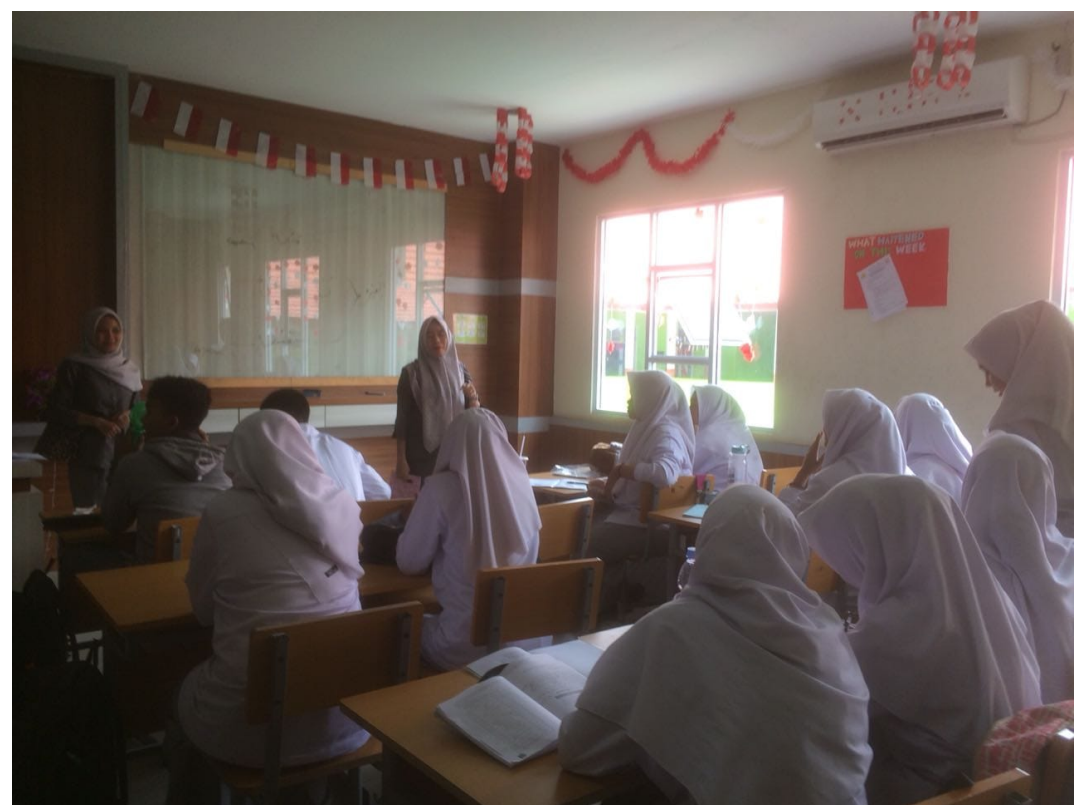

Gambar 1. Penyampaian materi pelatihan SADARI

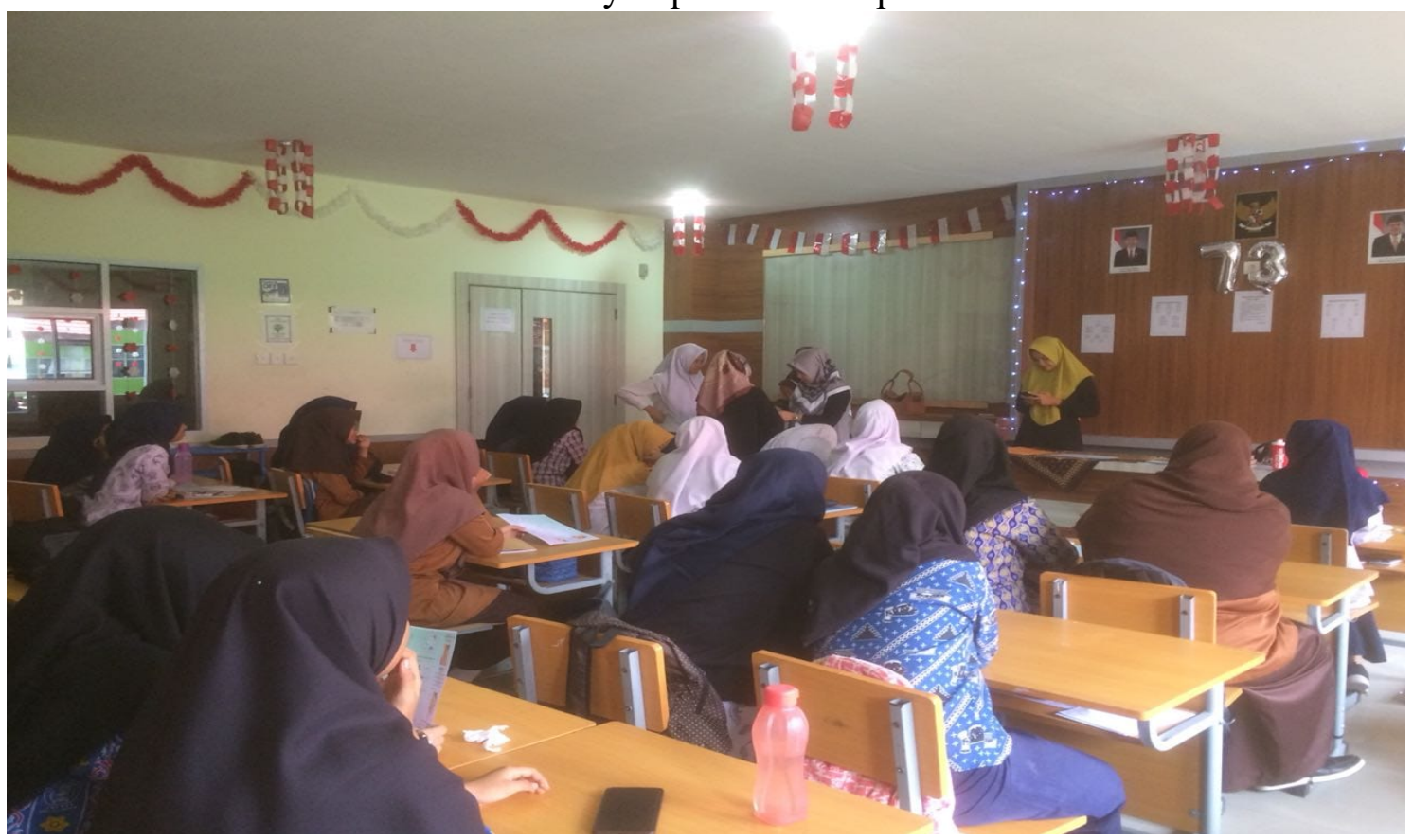




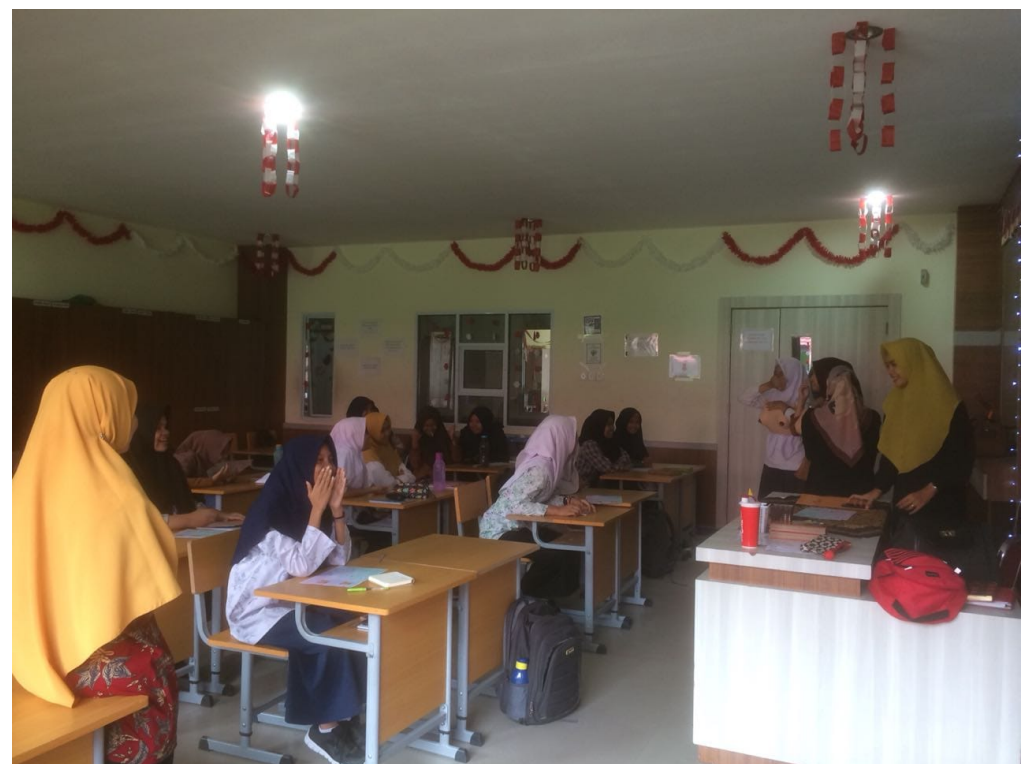

Gambar 2. Praktek menggunakan phantom

\section{B. Pembahasan}

SADARI merupakan kegiatan yang sangat penting untuk diketahui oleh remaja putri saat ini, karena $75-85 \%$ keganasan kanker payudara ditemukan pada saat pemeriksaan payudara sendiri. Berdasarkan data Sistem Infomasi Rumah Sakit (SIRS) bahwa kejadian Kanker payudara meningkat. Peningkatan pengetahuan seseorang dapat dilakukan dengan memberikan penyuluhan kesehatan.

Pada pelaksanaan pengabdian masyarakat tahap 1 yang dihadiri 20 orang siswi $100 \%$ sudah mengerti dan mau melaksanakan SADARI di rumah. Untuk tahap II yaitu evaluasi pelaksanaan SADARI dirumahnya, para siswa melakukan SADARI di rumah dan dapat mengajarkan teman sekolahnya masing-masing 2-3 orang untuk melakukan SADARI.

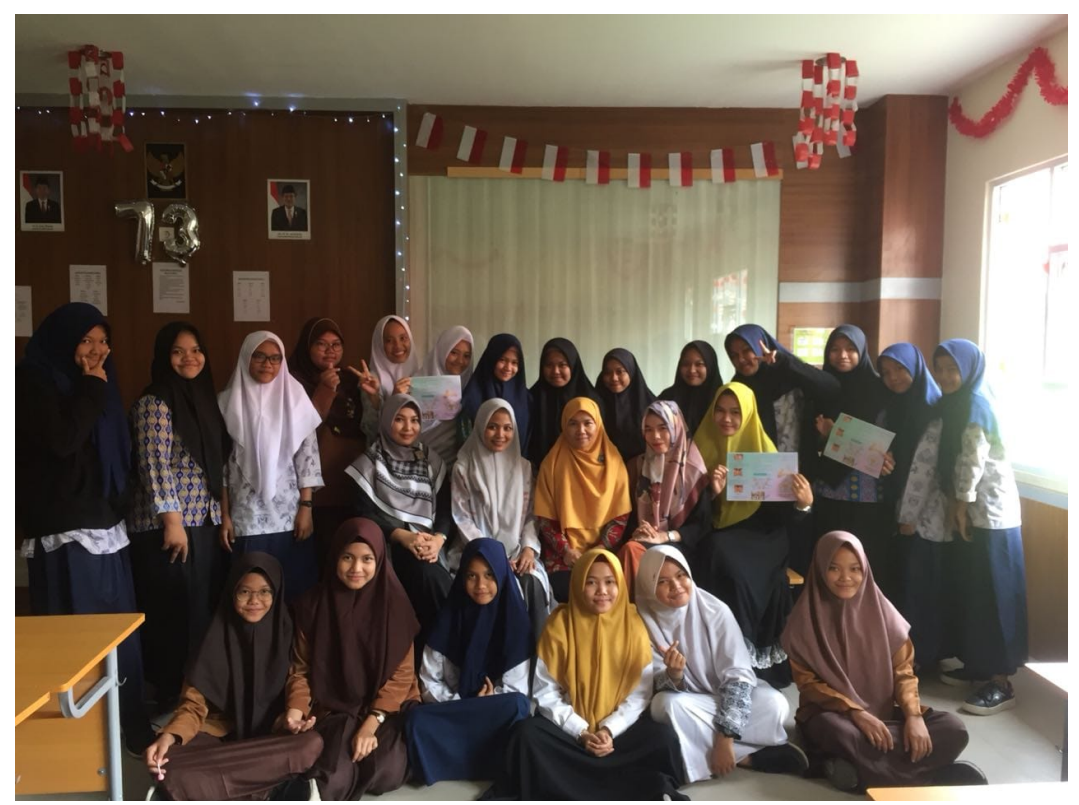

Gambar 3. Foto bersama peserta kegiatan 


\section{KESIMPULAN}

Dari kegiatan engabdian masyarakat ini dapat disimpulkan bahwa :

1. Pengetahuan remaja putri tentang pelaksanaan SADARI meningkat dilihat dengan dapat menjawab pertanyaan

2. Remaja putri melaksanakan SADARI dirumah

3. Remaja putri yang sudah mendapatkan pelatihan SADARI dapat mengajarkan teman-teman sekolahnya masing-masing 2-3 orang

\section{DAFTAR PUSTAKA}

[1]. Astana, M. (2009). Bersahabat Dengan Kanker. Yogyakarta: Araska

[2]. Husniati. (2012). Hubungan Pengetahuan dan Sikap Remaja Putri Dengan Pemeriksaan Payudara Sendiri di SMA Negeri I Trienggadeng Kabupaten Pidie Jaya, (Online),(http://180.241.122.205/dockti/HUSNIATI-11030045.pdf) Diakses 28 November 2014.

[3]. Nugroho, T. (2011). ASI dan Tumor Payudara. Yogyakarta: Nuha Medika

[4]. Purwoastuti, E. (2008). Kanker Payudara, Pencegahan dan Deteksi Dini. Yogyakarta: Kanisius.

[5]. Rasjidi, I. ( 2009). Deteksi Dini \& Pencegahan Kanker Pada Wanita. Jakarta: CV Sagung Seto.

[6]. Yanti. JS (2015). Hubungan Pengetahuan dan Sikap dengan Pelaksanaan Sadari di SMA 5 Pekanbaru. Jurnal Menara Ilmu Vol. IX Jilid 3 No.61 